\title{
Statin and MTHFR C677T Polymorphism in Patients with Cardiovascular Diseases
}

\section{Statin Kullanan Kardiyovasküler Sistem Hastalarında MTHFR C677T Polimorfizmi}

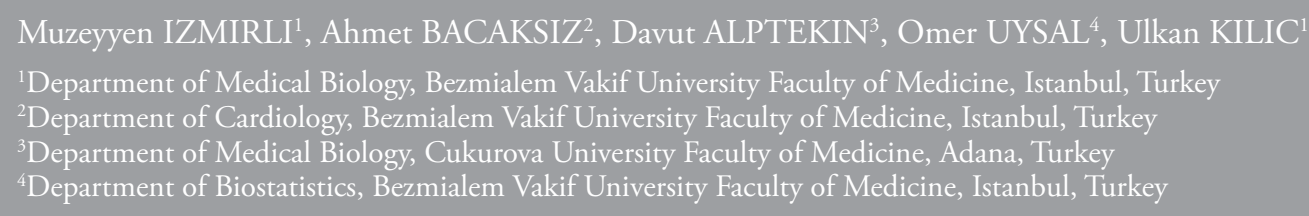

\section{ABSTRACT}

Objective: Cardiovascular disease (CVD) is the leading cause of death worldwide. The methylenetetrahydrofolate reductase (MTHFR) gene, located on the short (p) arm of chromosome 1 at position 36.3 (1p36.3), might be a possible risk factor for the pharmacogenetics in CVD. A common polymorphism in MTHFR $(\mathrm{C} 677 \mathrm{~T}, \mathrm{Ala} \rightarrow \mathrm{Val})$ decreases this enzyme activity and increases the homocysteine concentrations, predisposing one to heart disease. Alternatively, statins, cholesterol-reducing agents, are also used to reduce the homocysteine blood concentrations; the aim of the present study was to evaluate how the genotype frequencies of the MTHFR C677T polymorphism, namely rs1801133, change in the cardiovascular system in patients treated with statin.

Methods: In this study, the genotype distribution of the MTHFR C677T polymorphism in CVD patients treated with statin (hydrophilic and lipophilic) $(\mathrm{n}=290)$ and healthy controls $(\mathrm{n}=151)$ was assessed using polymerase chain reaction (PCR) and restriction fragment length polymorphism (RFLP).

Results: In this study, a statistically significant difference in genotype frequencies for the MTHFR C677T polymorphism was found between CVD patients treated with statin and controls $(\mathrm{p}=0.037)$.

Conclusion: For the first time, we demonstrate a relation between a MTHFR gene polymorphism and CVD in patients treated with statins in the Turkish population.

Key Words: MTHFR, cardiovascular disease, statin, pharmacogenetics

\section{ÖZET}

Amaç: Kardiyovasküler hastalıklar dünyada ölüm nedenlerinin başında gelmektedir. Kardiyovasküler hastalıkların farmakogenetiğinde muhtemel bir risk faktörü olan metilentetrahidrofolat redüktaz (MTHFR) enzimi, birinci kromozomun kısa (p) kolunun 36,3 bölgesinde (1p36.3) lokalize olan MTHFR geni tarafindan kodlanmaktadır. MTHFR geninde yaygın olan C677T (Ala $\rightarrow \mathrm{Val})$ polimorfizmi MTHFR enziminin aktivitesini azaltarak kalp hastalıklarına yatkınlığı artıran homosistein konsantrasyonunu artırır. Lipid düşürücü olarak kullanılan statinler aynı zamanda kandaki homosistein konsantrasyonunu da düşürmektedir. Bu çalışmada statin ile tedavi edilmekte olan kardiyovasküler sistem hastalarında MTHFR C677T polimorfizmi (rs1801133) genotip dağılımlarının araştırılması amaçlanmaktadır.

Yöntemler: Bu çalısmada, lipofilik ve hidrofilik statinler ile tedavi edilen kardiyovasküler sistem hastalarında $(\mathrm{n}=290)$ ve sağlıklı kontrollerde ( $\mathrm{n}=151)$ MTHFR C677T polimorfizmindeki genotip dağılımları incelenmiştir. Genotipleme, Polimeraz zincir reaksiyonu (PCR) ve restriksiyon parça uzunluk polimorfizm (RFLP) yöntemi ile yapılmıştır.

Bulgular: Bu çalışmada, MTHFR C677T polimorfizminin genotip dağılımında statin tedavisi gören kardiyovasküler sistem hastaları ile kontrol grubu arasında istatistiksel olarak anlamlı bir fark gözlenmiştir ( $\mathrm{p}=0,037)$.

Sonuç: Türk popülasyonunda statin ile tedavi edilen kardiyovasküler sistem hastaları ile MTHFR C677T polimorfizmi arasında istatistiksel olarak anlamlı bir ilişki ilk kez gösterilmiştir.

Anahtar Sözcükler: MTHFR, Kardiyovasküler Hastalıklar, Statin, Farmakogenetik 


\section{Introduction}

Cardiovascular disease (CVD) is the leading cause of death in Turkey (1). The conventional risk factors for CVD include genetic effects, hyperhomocysteinemia, smoking, hyperlipidemia, hypertension (HT), age, family history, diabetes mellitus (DM), and obesity (2).

Homocysteine, an amino acid intermediate in the conversion of methionine to cysteine, has been recognized as a new emerging risk factor for CVD (3). Methylenetetrahydrofolate reductase (MTHFR), a key enzyme in homocysteine metabolism (4), catalyzes the reduction of 5,10-methylenetetrahydrofolate to 5-methyltetrahydrofolate, a cosubstrate for methylation of homocysteine to methionine (5). The $M T H-$ $F R$ gene is located at the end of the short arm of chromosome 1 (1p36.3) (6). One of the well-described single-nucleotide polymorphisms of MTHFR is the C677T polymorphism, which stands in exon 4 and results in turning an alanine into valine at codon 222. This amino acid alteration causes an approximately $60 \%$ decrease in MTHFR enzyme activity compared to the wild-type in vitro. Therefore, MTHFR deficiency often results in elevated plasma homocysteine levels (7).

Pharmacogenetics is the study of how genetic factors affect inter-individual differences to treatment (8), and statin therapy has been largely investigated pharmacogenetically. Statins are a class of drugs used to lower cholesterol levels (9), and they also cause small reductions $(3.5 \%)$ in homocysteine blood concentrations (10). The previous studies clearly showed that statins are effective for treating cardiovascular disease by lowering cholesterol and homocysteine in the blood. Interindividual variation in response to statins (hydrophilic and lipophilic) is not sufficient to predict clinical benefit and adverse effects. As a consequence, more credible biomarkers are required for determining the sub-populations that may attain the most benefit from statin (hydrophilic or lipophilic) usage. However, as an individual therapy, the effect of statins in CVD is completely unclear. So, additional studies are needed to identify the contribution of individual statin therapies for CVD.

In the present study, we hypothesized that statins reduce homocysteine levels that are elevated by MTHFR enzyme deficiency due to MTHFR polymorphisms (rs1801133, C677T, Ala222Val). Thus, we investigated the relation of the C677T polymorphism in CVD patients under statin therapy and control groups in the Turkish population.

\section{Materials and Methods}

The study population consists of patients who diagnosed with CVD (n:290) under statin therapy at the Department of Cardiology (Bezmialem Vakif University) and healthy controls who came to the hospital for routine examination $(\mathrm{n}: 151)$. This study and all experimental procedures were approved by the ethical committee of Bezmialem Vakif University. Written in- formed consent was obtained from each participant. Three milliliters of venous blood was taken from subjects to blood tubes with EDTA. DNA isolation of the blood samples collected from both groups was performed by a precipitation method using a commercial DNA isolation kit (Invitrogen). The MTHFR C677T polymorphism was analyzed by PCR-RFLP methods as previously described (11). Briefly, the 198-bp PCR products were digested with $\operatorname{Hinf} I$ for 3 hours at $37^{\circ} \mathrm{C}$. Finally, genotypes were assessed on a $10 \%$ polyacrylamide gel.

\section{Statistical analysis}

The analysis of data was performed by the SPSS (11.5 version) program. To compare the ratios, the data were statistically analyzed by Pearson chi-square test. A 'p' value less than or equal to 0.05 was considered statistically significant.

\section{Results}

In the current study, we firstly determined the MTHFR C677T polymorphism in CVD patients under statin therapy. Initially, study groups were divided into three categories: a CVD group using lipophilic statin (lipo-statin), hydrophilic statin (hydrostatin), and a non-treatment (negative) control group. The frequencies of CC, CT, and TT variants were $40.8 \%, 46.1 \%$, and $13.1 \%$ for non-treatment; $47.7 \%, 39.6 \%$, and $12.6 \%$ for the lipophilic statin group; and $40.9 \%, 50 \%$, and $9.1 \%$ for the hydrophilic statin group, respectively. There was no statistically significant relation between statin therapy in CVD patients and MTHFR C677T variants $(\mathrm{p}=0,720)$.

The MTHFR C677T polymorphism was in Hardy-Weinberg equilibrium in CVD patients and the control group. The allele frequencies of $\mathrm{C}$ and $\mathrm{T}$ in CVD patients treated with statin were $62 \%$ and $38 \%$, respectively, and the allele frequencies regarding each of two alleles in the control group were $70 \%$ and $30 \%$, respectively (Table 1). According to the Pearson chi-square test, a statistically significant difference in the frequencies of the $\mathrm{T}$ allele was demonstrated between the CVD patients and controls

\begin{tabular}{|c|c|c|c|c|c|}
\hline & & $\begin{array}{l}\text { CVD } \\
\text { n (\%) }\end{array}$ & $\begin{array}{c}\text { Control } \\
\text { n (\%) }\end{array}$ & $\begin{array}{c}\mathrm{P} \\
\text { value }\end{array}$ & $\begin{array}{c}\text { OR } \\
\text { CI95\% }\end{array}$ \\
\hline \multirow{3}{*}{$\begin{array}{l}\text { Allele Frequencies } \\
1.06-1.93\end{array}$} & $C$ & 361 (62\%) & 212 (70\%) & 0.023 & 1.43 \\
\hline & & & & & \\
\hline & $\mathrm{T}$ & 219 (38\%) & 90 (30/\%) & & \\
\hline \multirow{5}{*}{$\begin{array}{l}\text { Total } \\
\text { Genotype }\end{array}$} & & $580(100 \%)$ & 302 (100\%) & & \\
\hline & & & & & \\
\hline & $\mathrm{CC}$ & 111 (38.3\%) & 77 (51\%) & 0.037 & \\
\hline & CT & 139 (47.9\%) & $58(38.4 \%)$ & & \\
\hline & $\mathrm{TT}$ & 40 (13.8\%) & $16(10.6 \%)$ & & \\
\hline Total & & 290 (100\%) & 151 (100\%) & & \\
\hline
\end{tabular}


for the studied polymorphism $(\mathrm{OR}=1.43$; CI 95\%=1.06-1.93; $\left.\mathrm{p}=0.023 ; \chi^{2}=5.181\right)$. The genotype frequencies of the CC, CT, and TT variants in the CVD patients were $38.3 \%, 47.9 \%$, and $13.8 \%$ for CVD patients under statin therapy and $51 \%, 38.4 \%$, and $10.6 \%$ for the control group, respectively. According to the Pearson chi-square statistical method (Table 1), there was a significant difference between the genotype frequencies of CVD patients and the MTHFR C677T polymorphism ( $\mathrm{p}=0.037$ ).

The MTHFR C677T genotype frequencies according to the presence (doing exercise at least 3 times in a week for $30 \mathrm{~min}$ ) or absence of exercise was also investigated. The genotype frequencies of CC, CT, and TT were $42.8 \%, 46.7 \%$, and $10.5 \%$ for the negative exercise group and $37.5 \%, 47.2 \%$, and $15.3 \%$ for the positive exercise group , respectively. However, the effect of exercise on the MTHFR C677T variants was insignificant $(\mathrm{p}=0.470)$.

\section{Discussion}

In the present study, we tested the hypothesis that the MTHFR C677T polymorphism is associated with CVD patients treated with statin (hydrophilic or lipophilic). When we analyzed the MTHFR gene polymorphisms, there were significant relations between the aforementioned polymorphism and CVD under statin therapy. However, we found that the MTHFR C677T polymorphism was not associated with differential statin efficacy. Additionally, in the present study, exercise has a protective role for the risk of CVD, even with possessing the mutant TT genotype.

In the literature, the relation between the MTHFR C677T polymorphism and the risk of CVD remains a controversial issue. Some previous studies reported a considerable difference between CVD patients and controls (12-15), while others had no difference (16-18).

It is known that cholesterol biosynthesis is inhibited by statins, limiting HMG-CoA reductase enzyme. Moreover, the action of statin is affected by MTHFR. In the literature, it was shown that the MTHFR C677T polymorphism causes high levels of homocysteine, which can be decreased by statins $(1,6)$. Recent studies suggested that multiple genetic factors, especially $M T H F R$, which plays a role in the methylation pathway, act for personal therapy $(19,20)$. However, in the present study, we could not find any relationship between the studied polymorphism and impact of statin.

The most important limitation of this study is that data on homocysteine values were not determined. Previous studies proved that MTHR polymorphisms elevate plasma homocysteine levels (21-23). On the other hand, statins cause small reductions (3.5\%) in homocysteine blood concentrations (10).

\section{Conclusion}

This is the first report on the genotype and allele frequencies under statin therapy and control subjects in the Turkish population. Statins, the most commonly prescribed lipid-lowering drugs, are generally effective for decreasing mortality in people with CVD. However, the efficiency of these agents differs from person to person due to comprehensive variability of genetic modifications. To predict the individual responses to drug therapies, the genetic differences of candidate molecules in metabolic mechanisms must be investigated. Further, molecular studies related with the association of the MTHFR C677T polymorphism and statin are needed for CVD individual treatment.

Ethics Committee Approval: Ethics committee approval was received for this study from the ethics committee of Bezmialem Vakif University (01.02.2012-7/15).

Informed Consent: Written informed consent was obtained from patients who participated in this study.

Peer-review: Externally peer-reviewed.

Author Contributions: Concept - U.K., M.I.; Design - U.K., M.I., O.U.; Supervision - U.K., M.I.; Funding - U.K., D.A.; Materials - U.K., A.B.; Data Collection and/or Processing - M.I., A.B., O.U., D.A.; Analysis and/or Interpretation - U.K., O.U.; Literature Review - M.İ., D.A., A.B.; Writing - U.K.; Critical Review - U.K.

Conflict of Interest: No conflict of interest was declared by the authors.

Financial Disclosure: The authors declared that this study has received no financial support.

Etik Komite Onayı: Bu çalışma için etik komite onayı Bezmialem Vakıf Universitesi'nden alınmıştır (01.02.2012-7/15).

Hasta Onamı: Yazılı hasta onamı bu çalışmaya katılan hastalardan alınmıştır.

Hakem değerlendirmesi: Dış bağımsız.

Yazar Katkıları: Fikir - U.K., M.I.; Tasarım - U.K., M.I., O.U.; Denetleme - U.K., M.I.; Kaynaklar - U.K., D.A.; Malzemeler - U.K., A.B.; Veri Toplanması ve/veya İşlemesi - M.I., A.B., O.U., D.A.; Analiz ve/veya Yorum - U.K., O.U.; Literatür Taraması - M.İ., D.A., A.B.; Yazıyı Yazan - U.K.; Eleştirel İnceleme - U.K.

Çıkar Çatışması: Yazarlar çıkar çatışması bildirmemişlerdir.

Finansal Destek: Yazarlar bu çalışma için finansal destek almadıklarını beyan etmişlerdir.

\section{References}

1. Gogen S. Heart health policies of the European Union and Turkey. Arch Turk Soc Cardiol 2011; 39: 248-53. [CrossRef]

2. Kathiresan S, Srivastava D. Genetics of human cardiovascular disease. Cell 2012; 148: 1242-57. [CrossRef]

3. Nygard O, Nordrehaug JE, Refsum H, Ueland PM, Farstad M, Vollset SE. Plasma homocysteine levels and mortality in patients with coronary artery disease. N Engl J Med 1997; 337: 230-6. [CrossRef]

4. McCully KS. Vascular pathology of homocysteinemia: implications for the pathogenesis of arteriosclerosis. Am J Pathol 1969; 56: 111-28.

5. Pavillard V, Drbal AA, Swaine DJ, Phillips RM, Double JA, Nicolaou A. Analysis of cell-cycle kinetics and sulfur amino acid me- 
tabolism in methionine-dependent tumor cell lines; the effect of homocysteine supplementation. Biochem Pharmacol 2004; 67: 1587-99. [CrossRef]

6. Goyette P, Pai A, Milos R, Frosst P, Tran P, Chen Z, et al. Gene structure of human and mouse methylenetetrahydrofolate reductase (MTHFR). Mammalian Genome 1998; 9: 652-6. [CrossRef]

7. Frosst P, Blom HJ, Milos R, Goyette P, Sheppord CA, Matthews $\mathrm{RG}$, et al. A candidate genetic risk factor for cardiovascular disease: a common mutation at the methylenetetrahydrofolate locus. Natt Genet 1995; 10: 111-3. [CrossRef]

8. Kitzmiller JP, Groen DK, Phelps MA, Sadee W. Pharmacogenomic testing: relevance in medical practice: why drugs work in some patients but not in others. Cleve Clin J Med 2011; 78: 243-57. [CrossRef]

9. Lewington S, Whitlock G, Clarke R, Sherliker P, Emberson J, Halsey J, et al. Blood cholesterol and vascular mortality by age, sex, and blood pressure:a meta-analysis of individual data from 61 prospective studies with 55.000 vascular deaths. Lancet 2007; 370: 1829-39. [CrossRef]

10. Jankowski P, Kawecka-Jaszcz K. Lipid-lowering drugs and homocysteine. A comparison between statins and other lipid-lowering drugs. Atherosclerosis 2004; 172: 191-4. [CrossRef]

11. Izmirli $\mathrm{M}$, Inandiklioglu $\mathrm{N}$, Abat $\mathrm{D}$, Alptekin $\mathrm{D}$, Demirhan $\mathrm{O}$, Tansug Z, et al. MTHFR gene polymorphisms in bladder cancer in the Turkish population. Asian Pasific J Cancer Prev 2011; 12: 1833-5.

12. Tripathi R, Tewari S, Singh PK, Aqarwal S. Association of homocysteine and methylene tetrahydrofolate reductase (MTHFR C677T) gene polymorphism with coronary artery disease (CAD) in the population of North India. Genet Mol Biol 2010; 33: 224-8. [CrossRef]

13. Wernimont SM, Clark AG, Stover PJ, Wells MT, Litonjua AA, Weiss ST, et al. Folate network genetic variation predicts cardiovascular disease risk in non-Hispanic white males. J Nutr 2012; 142: 1272-9. [CrossRef]

14. Yang Q, Bailey L, Clarke R, Flanders WD, Liu T, Yesupriya A, et al. Prospective study of methylenetetrahydrofolate reductase (MTH$\mathrm{FR}$ ) variant $\mathrm{C} 677 \mathrm{~T}$ and risk of all-cause and cardiovascular disease mortality among 6000 US adults. Am J Clin Nutr 2012; 95: 124553. [CrossRef]

15. Huang T, Tucker KL, Lee YC, Crott JW, Parnell LD, Shen J, et al. Methylenetetrahydrofolate reductase variants associated with hypertension and cardiovascular disease interact with dietary polyunsaturated fatty acids to modulate plasma homocysteine in puertorican adults. J Nutr 2011; 141: 654-9. [CrossRef]

16. Isordia-Salas I, Trejo-Aguilar A, Valades-Mejia MG, Santiago-German D, Leanos-Miranda A, Mendoza-Valdez L, et al. C677T polymorphism of the 5,10 MTHFR gene in young Mexican subjects with ST-elevation myocardial infarction. Arch Med Res 2010; 41: 426-50. [CrossRef]

17. Hussein AS. High prevalence of three prothrombotic polymorphisms among Palestinians: factor V G1691A, factor II G20210A and methylenetetrahydrofolate reductase C677T. J Thromb Thrombolysis 2012; 34: 383-7. [CrossRef]

18. Houcher B, Houcher Z, Touabti A, Begag S, Torun D, Eğin Y, et al. Association of methylenetetrahydrofolate reductase C677T and cystathionine $\beta$-synthase polymorphisms in cardiovascular disease in the algerian population. Genet Test Mol Biomarkers 2010; 14: 775-80. [CrossRef]

19. Thompson JF, Hyde CL, Wood LS, Paciga SA, Hinds DA, Cox DR, et al. Comprehensive whole-genome and candidate gene analysis for response to statin therapy in the Treating to New Targets (TNT) cohort. Circ Cardiovasc Genet 2009; 2: 173-81. [CrossRef]

20. Barber MJ, Mangravite LM, Hyde CL, Chasman DI, Smith JD, McCarty CA, et al. Genome-wide association of lipid lowering response to statins in combined study populations. PLOS One 2010; 5; e9763. [CrossRef]

21. Li Z, Sun L, Zhang H, Liao Y, Wang D, Zhao B, et al. Elevated plasma homocysteine was associated with hemorrhagic and ischemic stroke, but methylenetetrahydrofolate reductase gene C677T polymorphism was a risk factor for thrombotic stroke: a Multicenter Case-Control Study in China. Stroke 2003; 34: 2085-90. [CrossRef]

22. Joachim E, Goldenberg NA, Bernard TJ, Armstrong-Wells J, Stabler S, Manco-Johnson MJ. The methylenetetrahydrofolate reductase polymorphism (MTHFR 677C>T) and elevated plasma homocysteine levels in a U.S. pediatric population with incident thromboembolism. Thromb Res 2013; 132: 170-4. [CrossRef]

23. Ghassibe-Sabbagh M, Platt DE, Youhanna S, Abchee AB, Stewart $\mathrm{K}$, Badro DA, et al. Genetic and environmental influences on total plasma homocysteine and its role in coronary artery disease risk. Atherosclerosis 2012; 222: 180-6. [CrossRef] 